\title{
胸・腰椎部損傷の観血的治療
}

\begin{tabular}{|c|c|c|c|c|c|}
\hline 貴 & 船 & 雅 & 夫・弓 & 削 & 大四郎 \\
\hline 三 & 村 & & 寛・酒 & 井 & 和 \\
\hline 中 & 村 & 克 & 巳・伊 & 達 & 武 \\
\hline 堀 & 内 & 英 & 彦・東 & & 栄 \\
\hline
\end{tabular}

\section{Evaluation of Surgical Treatment for Thoracolumbar Spine Fracture} by

\author{
Masao Kifune, Daishiro Yuge, Hiroshi Mimura, \\ Kazuhiro Sakai, Katsumi Nakamura, Taketoshi Date, \\ Hidehiko Horiuchi and Eiji Azuma
}

Department of Orthopaedic Surgery, Yamaguchi Central Hospital, Yamaguchi, Japan

This study evaluated the clinical results of surgical treatment for thoracolumbar spine fracture. The subjects were 26 males and 3 females with a mean age of 47 years ranging from 18 to 74 years. The duration of the follow-up varied from 4 months to 72 months, with a mean of 2 years and 4 months. The most common site of injury was L1, which accounted for $55 \%$ of the injuries $(16 / 29$ cases). The causes of the injuries were 16 falls, 8 traffic accidents, and 5 heavy mass drops. Four kinds of instuments (Roy Comille plate : 16 cases, Kaneda device : 5, Compact CD :2, Spine system : 6) were used. We operated by the anterior approach for 5 cases, by the posterior approach for 15 cases, and by the anterior/posterior approach for 9 cases.

47 percent of the patients showed improvement of neurological deficits, increcsing by one rank by the Frankel classification. Although no cases deteriorated, 3 patients with complete paraplegia did not improve at all at the time of follow-up. The correction angle in 41 percent of the patients (12/29 cases), which was acquired by operation, decreased radiographically more than 6 degrees at the time of follow-up. No difference was seen in the correction loss between each implant or between each approach. We observed 11 fractures of the extremities, 3 pelvic fractures, 3 head injuries, 4 pulmonary hemorrhages with rib fractures, a cord injury of the cervical spine, a crush syndrome, and a fat embolism syndrome preoperatively. We recognized 8 doner site troubles, a sudden raputure of spleen, a numbness of prineum, etc postoperatively. 10 instrument failures (R-C plate : $6:$ cases, $\mathrm{K}$-device : 2, CCD : 1, S-system :1) were found at the time of follow-up. 4 out of 5 screw breakages were $R-C$ plate system, because the screw diameter of $R-C$ was smaller than others.

Key words : Thracolumbar spine (胸腰椎), burst fracture（破裂骨折), instrumentation (インストゥ ルメンテーション)

はじめに

胸・腰椎部損傷の観血的治療においてはさまざまな instrument が用いられる。当院では 1983 年以降 Roy-Comille plate を用いて治療を行ってきた. し かしながら，最近では固定範囲の縮小などあ考虑し他 
の instrument に変更している. そこで，過去 10 年間 （1987 年〜）に spinal instrumentation を用い治療 した胸・腰椎部損傷について Roy-Comille plate と 最近の system について臨床的検討を行ったので報告 する.

\section{対 \\ 象}

症例は胸・腰椎部損傷 29 例で, その内訳は年令 18 74 歳 (平均 47 歳), 男性 26 例, 女性 3 例であ。 た. 受傷原因は転落 16 例, 交通事故 8 例, 重量物落 下 5 例となっていた。損傷レベルは T11：1例，T12： 5 例, L1 : 16 例, L2 : 7 例, L3 : 5 例, L4 : 1 例で あり, 他のレベルでの椎体圧迫骨折合併む6例認めた.

手術適応は不安定型の胸腰椎移行部損傷を対象とし, 損傷形態は破裂骨折 26 例, 脱臼骨折 4 例（隣接下位 の破裂骨折 2 例含), chance 骨折 1 例であった.

術式選択は主たる損傷が前方で脊柱管内の骨片が神 経を圧迫しているものは前方除圧（前方法もしくは前・ 後方法）を，主たる損傷が後方であるものは後方法を 原則として選択した，一方で主たる損傷が前方であっ てあ，神経症状を有せず脊柱管内の骨片が比較的小さ い例では後方法で対応した．使用 instrument は Roy - Comille plate, Kaneda device, Compact CD, Spine system の 4 種類であった。 また固定範囲は Roy-Comille plate でのみ 2 above 2 below で, そ の他は 1 above 1 below を原則とした ${ }^{6)}$.

術式別に見ると前方法 $(A)$ を5例に, 後方法 $(P)$ を 15 例に, 前・後方法 (A P ) を 9 例に施行した. instrument別では Roy-Comille plate 16 例（AO : P9 : AP7), Kaneda device 5 例 (A5 : P0 : AP0), Compact CD 2 例 (A0 : P5 : AP0), Spine system 6 例（A0 : P5 : AP1）であった.

Roy-Comille plate はRoy-Comilleによって考案 （1963）された最初の脊椎後方固定用 plate - screw system (vitallium 製) で， 4 穴 $49 \mathrm{~mm}$ から 21 穴 $270 \mathrm{~mm}$ まである ${ }^{5)}$. 穴と穴との間隔は $13 \mathrm{~mm}$, screw と Plate は semirigid で, 穴に約 $5{ }^{\circ}$ の自由度 がある。 また screw は外径 $4.5 \mathrm{~mm} /$ 内径 $3.2 \mathrm{~mm}$ で 胸腰椎部では 38〜 $45 \mathrm{~mm}$ のものを使用している. Kaneda device は金田により考案（1980）された前 方プレートである ${ }^{3)}$. rigid で前方プレートでは最む 強固なうちの一つで，今回使用したものはすべてステ ンレス製であった. screw は外径 $6.0 \mathrm{~mm} /$ 内径約 4.1 mm である. Compact CD は Cotrel \& Dubousset により考案された rigid な pedicle screw \& rod system である ${ }^{1)}$. 今回使用したものはすべてステンレス 製で, screw は外径 $6.0 \mathrm{~mm} /$ 内径 $3.9 \mathrm{~mm}$ である. Spine systemは Marnay Thierryにより考案され た pedicle screw \& rod system (チタン製) であ る. $\operatorname{rod} の$ 使い分けにより rigid \& semirigid の両方 に使い分けできる. また screw は外径 $6.0 \mathrm{~mm} /$ 内径 $4.0 \mathrm{~mm}$ である.

\section{検 討 項 目}

検討項目はX線にて損傷椎体の上下椎を含めた後彎 の推移, 神経学的な評価と合併症である. 追跡調查期 間は最長 6 年（平均 2 年 4 力月）であった。後彎角は 損傷椎体の一つ上下位椎体のそれぞれの上下縁の成す 角度を計測した。神経学的評価はFrankel 分類を, 合併症は術前・術中・術後で各々調查した。

\section{結果}

脊椎後㻭角は前方法では術前 $20.4^{\circ}$, 術後 $11.8^{\circ}$ が, 調查時 $18^{\circ}$ 人, 後方法では術前 $11.8^{\circ}$, 術後 $2.6^{\circ}$ が, 調查時 $10.1^{\circ}$, 前方後方法では術前 $11.6^{\circ}$, 術後 $2.3^{\circ}$ が, 調查時 $6.4^{\circ}$ となっていた（図 1 ). どの術式 でも手術による矯正は調查時には減少していたが, 症 状の憎覀につながった例はなかった。また Instrument 別での後禁角の変化も同様で Roy-Comille plate では術前 $10.6^{\circ}$, 術後 $1.6^{\circ}$ が, 調查時 $9.3^{\circ}$, Kaneda device では術前 $20.4^{\circ}$, 術後 $11.8^{\circ}$ が, 調查 時 $18^{\circ}$ へ, Compact $\mathrm{CD}$ では術前 $10.5^{\circ}$, 術後 $2.0^{\circ}$ が, 調查時 $3.0^{\circ}$ へ, Spine system では術前 $15.5^{\circ}$, 術後 $6.5^{\circ}$ が, 調查時 $9.4^{\circ}$ であった（図 2$)$. 調查時に $6^{\circ}$ 以 上後彎の増強した例は 12 例で内訳は R-C plate $8 / 16$ 例, $\mathrm{K}$ device $2 / 5$ 例, CCD $1 / 2$ 例, system $1 / 6$ 例 であった。

Frankel 分類を用いた神経症状の推移は神経症状を 有した 19 例中 9 例（47\%）に一段階の改善を認めた. 一方で Frankel Aの 3 例は全く改善しなかった（図 $3,4)$

術前合併症は四肢骨骨折が 11 例, 骨盤骨折・頭部 外傷が各々 3 例で, 血気胸を 4 例に認めた. 特に血胸 は来院時の胸写にほとんど異常がなくてあ時間の経過 とともに進行し重篤となる場合むあった，そのため肋 骨骨折がある場合には血気胸の進行を念頭に置く必要 


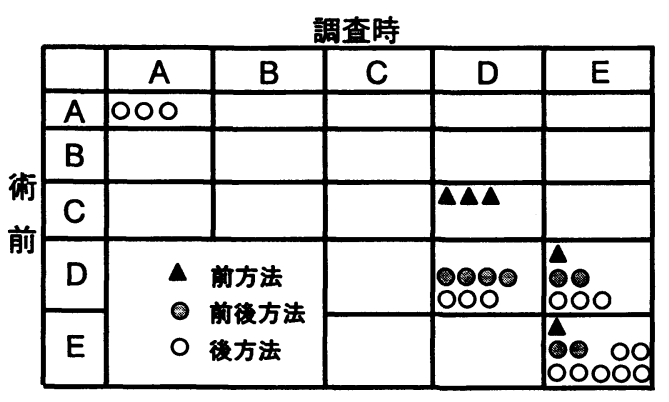

図 1 神経機能評価（術式別）

調查時

\begin{tabular}{|c|c|c|c|c|c|}
\hline & A & B & C & D & $E$ \\
\hline A & $\Delta \Delta O$ & & & & \\
\hline B & & & & & \\
\hline C & & & & $\Delta \Delta \Delta$ & \\
\hline D & \multirow{2}{*}{\multicolumn{2}{|c|}{$\begin{array}{l}\Delta \text { Kaneda device } \\
\Delta \text { Roy-Comille plate } \\
0 \text { Compact CD } \\
\text { O } \text { Spine system }\end{array}$}} & & ดิิํํㅅ & $\Delta \Delta \Delta$ \\
\hline$E$ & & & & & $\begin{array}{l}\Delta \Delta \Delta \Delta \Delta \Delta \\
\Delta \Delta, 0 \circ\end{array}$ \\
\hline
\end{tabular}

図 2 神経機能評価 (Instrument 別)

がある．また頸髄損傷・挫隇症候群・脂肪塞栓も各 1 例あった。

術中合併症としては, 神経症状を呈さなかった馬尾 神経損傷を 1 例認めた。術中出血量は前方で平均 $2794 \mathrm{~g}$ (1400-5300), 前後方が平均 $2248 \mathrm{~g}$ (11923800), 後方で $1394 \mathrm{~g}$ (124-3544) となっていた． 総 輸血量は前方で平均 $1888 \mathrm{~g}$ (600-4240), 前後方が平 均 $1800 \mathrm{~g}(560-3000)$, 後方で $793 \mathrm{~g}(0-3150)$ となっ ていた。

術後合併症では採骨部障害を 21 例中 8 例に認めた。 内訳は疼痛しびれが 6 例，骨折 2 例であった。一過性 精神障害・体動開始後の脾膕損傷の顕在化・毫引手術 台による会陰部しびれを各 1 例に認めた. Instrument failure は 29 例中 10 例（34\%）に認めた。 RCplate では 16 例中折損 5 例 - screw backout 1 例, Kaneda device では 5 例中ゆるみ 1 例, cut-out 1 例に, CCD では 2 例中折損を 1 例に, Spine system では 6 例中ゆるみを 1 例に認めた。

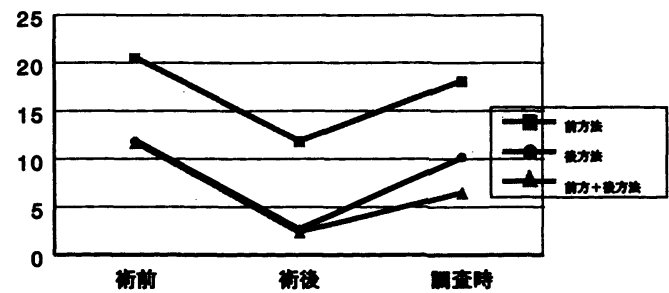

図 3 春椎後篎角の推移（術式別）

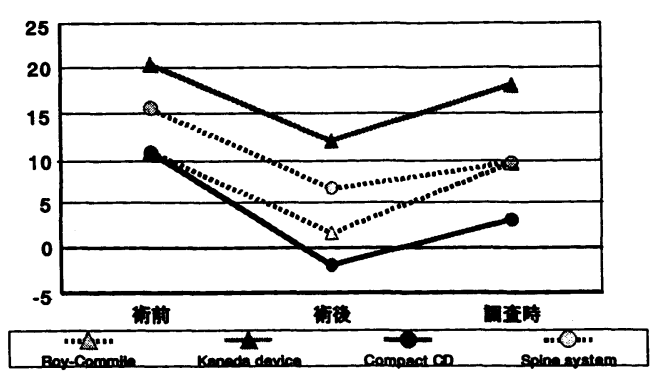

図 4 脊椎後角の推移 (Instrument 別)

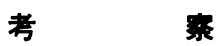

一般に椎体の anterior column, middle column の損傷では前方固定が有利と言われている，しかしな がら今回の術式別での後管角镉正損失に差は認めなかっ た. 前方固定の後彎角変化を見ると 2 例で screw の cutout やloosening が生じていた，後彎增強した 1 例は年令が高く，椎体の脆弱性が固定力を低下させて いたと考えた．実際各術式別の背景を見ると前方法を 行った群では平均年齢は 59 歳で他の 2 群（後方法 42 歳・前後方法 52 歳）に比し高くなっていた. Spine system でのゆるみを生じた 1 例は多発外傷の輸血拒 否例で, limited operation であったことが原因であ り instrument の問題ではなかった.

神経症状の改善では完全麻㾴例が不変であったのは 胸腰椎では Frankel らは 126 例中 102 例 (81\%) と, 森・芝らす 161 例中 151 例（94\%）之報告している ${ }^{24)}$. 我々の症例では Frankel A では全例改善を認めなかっ た. Frankel らは改善の見られたものは $35.1 \%$ と報告 
していたが，我々の症例では $47 \%$ となっていた。術 式別, Instrument 別での明らかな差は見いだせなかっ た.

今回の Instrument failure のうち screw の折損は R-C screw に多かった。 これはR-C screw 外径が $4.5 \mathrm{~mm}$ と他のものより細いことや固定範囲が広いた めに生じる両サイドでの過度なストレスが主因と考え られた。 ただ,この instrument failureによる臨床 症状の憎悪は認めていない。 また Compact CD では screw の形状より stress の集中部が存在し，折損は ネジ山のない部分からある部への移行部で起こってい た.

instrument 優劣を臨床成績からのみ論じることは 難しい，成績に差がなければ固定椎間が少ないことや 操作性の容易さが前方であれ後方であれ instrument 選択の基本と思われる.この点では R-C plate は固 定範囲が広く (2 above 2 below), Plate の穴に pedicle screw の位置を合わせなければならない頻雑 さと難しさがあり他の instrument に劣ると思われた。

$$
\text { ま と め }
$$

1. 観血的治療を行った 29 例について検討した.

2. 調查時 29 例中 12 例に後彎角の增大が見られた。
3. 神経症状の改善は 29 例中 9 例に認めた.

4. 術後合併症として採骨部障害が 21 例中 8 例に 存在した.

5. instrument の折損は screw 径の細い R-C plate systemに多かった.

\section{参考文献}

1) Cotrel Y., Dubousset J. : Nouvelle technique d'osteosynthese rachidienne segmentaire par voie posterieure. Revue de Chirurgie Orthopedique $70: 489$ $-494,1984$.

2) Frankel HL., et al. : The value of postural reduction in the initial management of closed injuries of the spine with paraplegia and tetraplesia. Paraplesia, 7 : 179-192, 1969.

3) Kaneda, K., et al. : Burst fractures with neurologic deficits of the thoracolumbar spine. Spine $9: 788-795$, 1984.

4）森 栄治, 芝啓一郎 : 胸腰椎損傷治療における合併症, 治療難航例. MB Orthop $9:$ : 95-105, 1996.

5) Roy-Comille, R., et al. : Internal fixation of the lumbar spine with pedicle screw plating. Clin. Orthop. $203: 7-17,1986$.

6）田口敏彦, 他 : 胸・腰椎部脊椎損傷に対するRoyComille Plate 固定について. 整形外科と災害外科 41 : 335-338, 1992. 